\title{
KAPASITAS ADAPTIF MASYARAKAT PESISIR MENGHADAPI PERUBAHAN IKLIM : KASUS PULAU GANGGA, MINAHASA UTARA
}

\section{The Adaptive Capacity of Coastal Communites Face Climate Change: Gangga Island Case, South of Minahasa}

\author{
Ary Wahyono, Masyhuri Imron dan Ibnu Nadzir \\ Peneliti Puslit Kemasyarakatan dan Kebudayaan-LIPI \\ Email : ary318@gmail.com
}

Diterima 24 Oktober 2013 - Disetujui 29 Nopember 2013

\begin{abstract}
ABSTRAK
Masyarakat pesisir merupakan salah satu kelompok masyarakat yang paling rentan menghadapi perubahan iklim. Perubahan kecil pada lingkungan mereka dapat memberikan dampak langsung pada kehidupan masyarakat pesisir khususnya pada sistem mata pencaharian. Nelayan misalnya, akan kesulitan untuk melaut dalam situasi cuaca yang tidak menentu. Situasi semacam ini juga dialami oleh berbagai mata pencaharian lain di wilayah pesisir, seperti penambak garam maupun ikan. Lebih lanjut, perubahan ekologis ini dapat berpengaruh pada kapasitas adaptif masyarakat pesisir. Tulisan ini mengangkat isu perubahan iklim yang terjadi pada masyarakat pesisir di Pulau Gangga. Informasi dari tulisan ini diperoleh dari wawancara dan FGD yang dijelaskan dengan kerangka konsep kapasitas adaptif. Tulisan ini menunjukkan bahwa fenomena perubahan iklim telah secara nyata dirasakan di Pulau Gangga. Meskipun demikian, gejala ini belum dianggap sebagai masalah yang signifikan oleh warga. Hal tersebut dipengaruhi oleh pengetahuan warga yang terbatas mengenai gejala perubahan iklim. Temuan lainnya menunjukkan bahwa kapasitas adaptif tidak hanya ditentukan oleh lingkungan. Struktur sosial baik dalam relasi patron-klien maupun kelembagaan di tingkat desa amat berpengaruh pada kapasitas adaptif masyarakat Pulau Gangga.
\end{abstract}

Kata Kunci: kapasitas adaptif, struktur sosial, perubahan iklim, Pulau Gangga

\begin{abstract}
Coastal communities are one of the most vulnerable groups to climate change. Little environmental change contributes to direct impact on the lives of coastal communities specifically on livelihood systems. Fishermen, for example, will find it hard to go to sea in a situation of erratic weather. Such a situation also faced by many other livelihoods in coastal areas, such as salt and fish farmer. Furthermore, these ecological changes may affect the adaptive capacity of coastal communities. This paper raised the issue of climate change on coastal communities on the island of Gangga Island.To explain the problem this paper uses interview and focus group data that is described through adaptive capacity framework. This paper shows that the phenomenon of climate change has been affecting coastal communities in Gangga Island. Nevertheless, this phenomenon has not been regarded as a significant problem by the citizens. It is influenced by the limited knowledge of the citizens about the symptoms of climate change. Other findings indicate that adaptive capacity is not only determined by the environment. Social structure in both the patron-client and institutional at the village level is very influential on the adaptive capacity of society Gangga Island
\end{abstract}

Keywords: adaptive capacity, social structure, climate change, Gangga Island 


\section{PENDAHULUAN}

Masyarakat pesisir merupakan karakteristik masyarakat yang seringkali direpresentasikan sebagai kaum nelayan, yang sumber kehidupannya tergantung dari sumberdaya alam yang terdapat di sekitarnya, yaitu perairan pesisir. Secara fisik, perairan pesisir adalah daerah pertemuan darat dan laut, dengan batas darat meliputi bagian daratan, baik kering maupun terendam air yang masih mendapat pengaruh sifat-sifat laut, seperti angin laut, pasang surut, dan intrusi air laut. Ke arah laut, perairan pesisir mencakup bagian batas terluar dari daerah paparan benua yang masih dipengaruhi oleh proses-proses alami yang terjadi di darat, seperti sedimentasi dan aliran air tawar.

Nelayan hidup dalam suatu lingkungan yang tidak menentu (uncertainity) dan serba tidak homogen. Ketidak-menentuan yang menjadi karakteristik kehidupan nelayan berakar dari kondisi lingkungan fisik, dan juga dari lingkungan sosial tempat kegiatan nelayan berlangsung. Laut adalah lingkungan fisik tempat nelayan mencari ikan atau biota laut lainnya, yang merupakan lingkungan yang berbahaya, dan manusia hanya dibekali kemampuan terbatas untuk dapat hidup di atasnya. Artinya, nelayan memerlukan peralatan atau teknologi tertentu untuk melakukan aktivitas di laut.

Di dalam laut terdapat berbagai macam biota atau binatang laut yang beraneka ragam ukuran, sifat kehidupan dan tingkah-lakunya. Ikan adalah contoh biota laut yang tidak mudah ditangkap. Letak kesulitan terjadi bukan hanya karena ikan berpindah-pindah atau migrasi sesuai dengan musimnya, melainkan juga karena jumlahnya dapat bertambah atau berkurang, sehingga para ahli perikanan tidak mudah untuk memperkirakan kecenderungan-kecenderungan yang terjadi (Acheson, 1981).

Demikian halnya apabila nelayan berhasil melakukan penangkapan ikan, belum tentu bisa menjamin penghasilan yang memadai. Hal ini terjadi karena nelayan memiliki keterbatasan untuk bisa mengikuti mekanisme pasar. Keterbatasan ini terjadi juga karena nelayan secara fisik tidak selalu ada di daratan. Belum lagi faktor tingkat fluktuasi harga ikan di pasar yang begitu tinggi dan sangat sulit diramalkan, sehingga semakin menambah ketidakpastian (Acheson, 1981). Singkatnya, kegiatan nelayan pada level produksi maupun pemasaran hasil tangkapan dihadapkan pada berbagai persoalan yang diakibatkan oleh karakteristik lingkungan yang penuh ketidakpastian.

Usaha perikanan sangat bergantung pada musim, harga dan pasar, sehingga sebagian besar karakter masyarakat pesisir tergantung pada faktorfaktor tersebut. Hal ini menyebabkan masyarakat pesisir sangat rentan terhadap perubahan fisik lingkungan dan iklim. Untuk mengatasi hal tersebut mereka cenderung meminimalkan kemungkinan kegagalan usaha dari pada mencari peluang untuk mendapatkan hasil maksimal, karena kegagalan usaha berarti mengancam eksistensi mereka. Berkaitan dengan hal tersebut, tulisan ini dimaksudkan untuk menjelaskan seberapa besar masyarakat mengembangkan kapasitas adaptif sebagai bentuk tanggapan atau mengatasi bahaya, kerentanan dan risiko yang timbul akibat perubahan fisik lingkungan sebagai dampak perubahan iklim.

\section{METODOLOGI}

\section{Pendekatan Studi}

Kapasitas adaptif masyarakat pesisir menghadapi perubahan iklim dapat dibedakan menjadi tiga model, yakni : (1) kajian kerentanan sosial yang menfokuskan pada identifikasi kondisi kerentanan perorangan dan tempat akibat adanya kejadian alam yang ekstrem; (2) kajian kerentanan yang berangkat dari asumsi bahwa kerentanan adalah suatu kondisi sosial yang merupakan ukuran resistensi dan resilensi sosial terhadap suatu bencana; dan (3) kajian yang menjelaskan interaksi antara exposure yang potensial dan resiliensi sosial pada tempat atau wilayah tertentu (Susan, 2003).

Model pertama lebih menekankan pada exposure climate change and socio economic change; resiko seperti apa yang dihadapi, atau kemungkinan terjadi bencana yang dapat membawa hasil yang tidak diinginkan. Resiko adalah kerugian yang terjadi dalam sistem matapencaharian akibat kejadian bencana alam tertentu. Di dalam dunia kenelayanan, misalnya hilangnya sumerdaya ikan, ongkos melaut yang semakin bertambah, dll. Exposure climate change menunjuk pada kehadiran bencana pada perorangan, rumah tangga, atau kelompok sosial. Oleh sebab itu, kerentanan sering diartikan sebagai a fuction of axposure to risk or as measure of coping capabilities (Seth Tuler et al., 2008). Dengan demikian, salah satu upaya mengukur indikator kerentanan sosial (social vulnerability) berangkat dari pemahaman bahwa 
kerentanan social menunjuk pada keterpaparan yaitu penerimaaan terhadap terpaan suatu bahaya atau terdapatnya kondisi stress di tingkat kelompok atau perorangan akibat terpaan suatu bahaya. Tingkat kerentanan masyarakat tersebut sangat dipengaruhi oleh faktor akses terhadap sumber daya alam dan diversitas sumber-sumber pendapatan. Kerentanan dapat berubah setiap saat dalam jangka pendek atau jangka panjang tergantung seberapa besar perubahan adaptasi : karakter ancaman, exposure to the treaths, sensitivitas, dan usaha pemulihan yang menghasilkan hasil cepat.

Model kedua terkait dengan kondisi ketahanan masyarakat pesisir, juga sering disebut dengan istilah resilensi (resilience) atau kelenturan terhadap bahaya yang dipicu oleh perubahan iklim. Ketahanan masyarakat atau juga berartik kapasitas adaptasi masyarakat untuk mempertahankan kondisinya dari bahaya perubahan iklim. Oleh sebab itu, pengembangan adaptasi masyarakat merupakan cara yang harus dilakukan dalam mengembalikan ketahanan masyarakat atau akibat perubahan iklim. Strategi meningkatkan ketahanan masyarakat terhadap bahaya yang dipicu oleh perubahan iklim yang bertujuan pemulihan atau mengembalikan keadaan semula dapat dilakukan dengan berbagai cara adaptasi, antara lain dengan pendekatan adaptasi berbasis masyarakat melalui jaringan atau net-working, atau dengan pendekatan budaya dan kearifan lokal. Pengembangan adaptasi masyarakat tersebut juga dapat digerakan oleh kebijakan pemerintah (Gambar 1).

Model ketiga yang menjelaskan interaksi antara exposure yang potensial dan resiliensi sosial pada tempat atau wilayah tertentu lebih tertuju pada sensitivitas [sensitivity]. Sensivitas menunjuk pada derajad dimana individu atau kelompok mengalami kerugian ketika bencana menimpanya. Dengan demikian, sensivitas berkaitan dengan frekuensi orang atau kelompok menghadapi bencana tersebut. Oleh sebab itu, seberapa besar individu atau kelompok sosial memiliki sensivitas dipengaruhi karakteristik masyarakat. Pengertian sensivitas ini sering dihadapkan dengan resiliensi. Dalam dunia kenelayanan misalnya, upaya untuk meningkatkan kerentanan seringkali berakibat nelayan tidak memiliki sensivitas tergadap bencana yang kemungkinan dapat menyebabkan reskio kerugian (Seth Tuler et al., 2008).

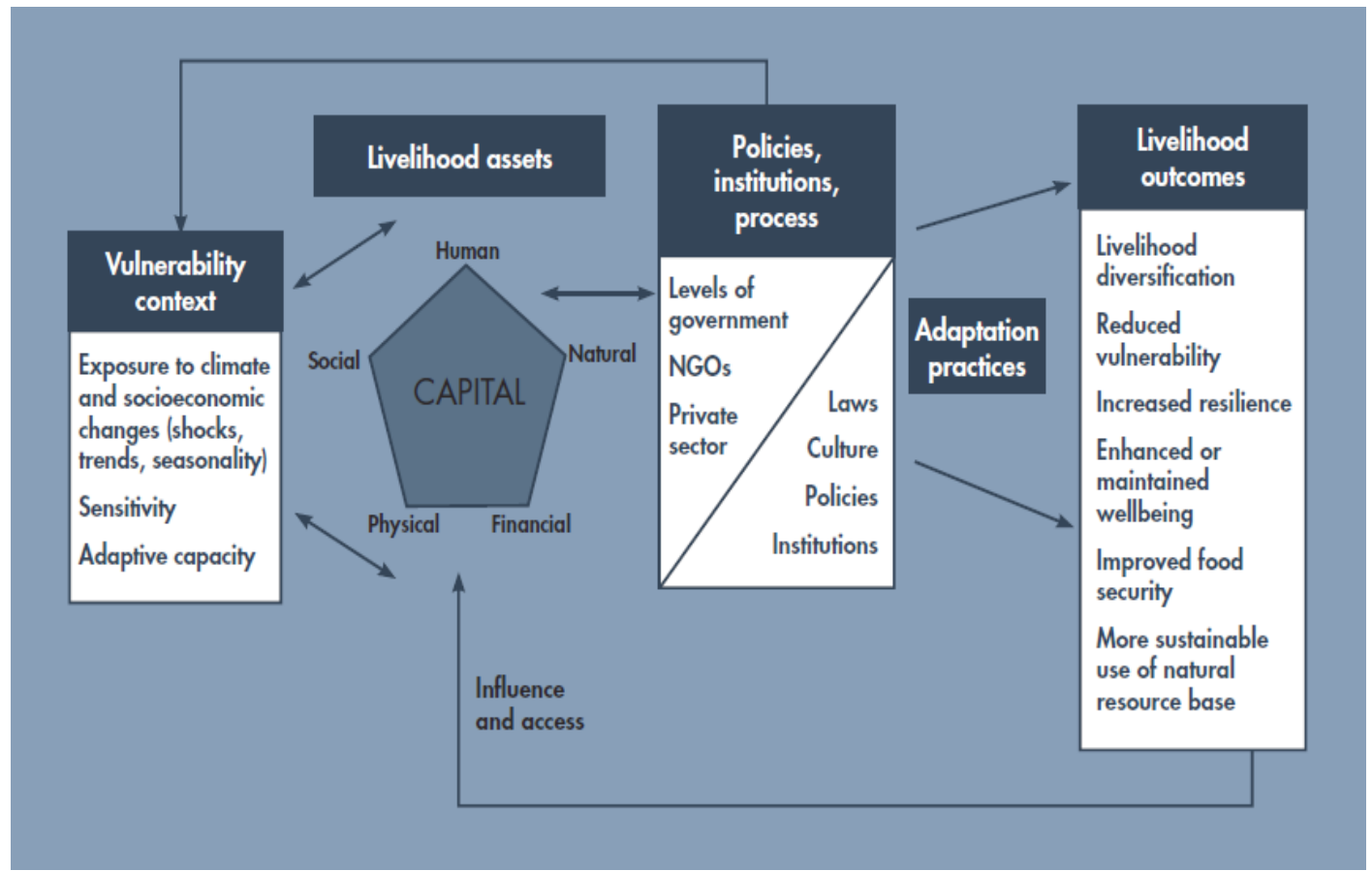

Gambar 1. Konsep Pendekatan Sustainable Livelihoods dalam Perubahan Iklim. Figure 1. Approaching of Sustainable Livelihoods Concept in Climate Change.

Sumber : [Mirjam Macchi, Amanda Manandhar Gurung, Brigitte Hoermann, Dhrupad Choudhury. 2011. Climate Variability And Change In The Himalayas Community Perceptions And Responses. Nepal : International Centre for Integrated Mountain Development]. Hal. 1] 
Secara ringkas dari uraian di atas dapat disimpulkan bahwa konsep kerentanan dapat dilihat dari (1) exposure to climate and socio economic changes, (2) sensitivity, dan (3) adaptive capacity. Tingkat kerentanan masyarakat juga saling berkaitan dengan livelihood asset. Dilihat dari ketiga substansi kerentanan tersebut, maka terdapat jenis mata pencaharian yang paling rentan terhadap dampak perubahan iklim. Tingkat kerentanan masyarakat tersebut ditentukan oleh kebijakan, kelembagaan dan proses-proses intervensi langsung yang dilakukan, baik oleh pemerintah, LSM atau lembaga swasta lainnya. Dari kebijakan dan intervensi program tentunya mempermudah masyarakat mengatasi kerentanan atau kemiskinan yang dihadapi atau dengan kata lain dengan tumbuh modal sosial, modal kapital, modal sumberdaya dan modal sumberdaya manusia sehingga masyarakat memiliki kapasitas adaptasi yang meningkat terutama untuk menghadapi bencana atau ancaman akibat perubahan iklim. Dengan tumbuhnya berbagai modal sosial, kapital dan sebabagainya akan mendorong masyarakat bertindak mengatasi kerentanan yang tergambar dari adanya penganekaragaman matapencaharian, aksi peningkatan ketahahan pangan pangan, dan sebagainya (Gambar 1).

\section{Lokasi Penelitian}

Tulisan ini bagian dari hasil penelitian di kabupaten Minahasa Utara, yaitu Pulau Gangga. Pulau inidipilih sebagai lokasi penelitian dianggap merepresentasikan kehidupan masyarakat berbasis mata pencaharian di laut yang berbasis kepulauan. Seperti Pulau Gangga terbagi menjadi dua desa, yakni Gangga 1 dan Gangga 2. Secara administratif kedua desa ini terletak dibawah satu hukum tuan yang mendiami wilayah Desa Gangga 1. Meskipun dikelola oleh hukum tua yang sama kedua wilayah ini memiliki perbedaan sosiologis yang cukup jelas. Sebagian besar penduduk Desa Gangga 2 memeluk agama Islam, sedangkan sebagian besar penduduk Desa Gangga 1 memeluk agama Kristen. Perbedaan corak masyarakat ini sangat penting untuk diketahui untuk dapat menentukan institusi sosial yang berpengaruh.
Wilayah perairan Pulau Gangga sudah ditetapkan jadi Kawasan Daerah Perlindungan Laut, sehingga penduduknya sering mendapatkan sosialisasi mengenai pentingnya perawatan ekosistem termasuk terumbu karang. Faktor lainnya adalah dibangunnya resort wisata yang menjual keindahan pantai dan terumbu karang sebagai daya tarik utama. Dengan demikian perawatan terumbu karang Pulau Gangga didukung oleh pemerintah, penduduk setempat, dan investor di tempat tersebut. Meskipun demikian Pulau ini kondisi ekosistemnya masih kurang baik. Bakau di di pulau ini masih kurang baik karena kerap ditebang untuk keperluan sehari-hari penduduk ${ }^{2}$. Kondisi serupa juga dialami oleh terumbu karang di wilayah ini. Praktik pengeboman dan peracunan ikan berdampak pada buruknya kehidupan terumbu karang. Namun, khusus untuk perawatan terumbu karang sudah mengalami peningkatan yang cukup signifikan.

Aktifitas penangkapan ikan di wilayah Kabupaten Minahasa Utara dipengaruhi adanya empat musim angin. Musim Selatan terjadi sekitar bulan Juli sampai Oktober. Periode berikutnya adalah musim Barat yang berlangsung antara bulan Oktober sampai Desember. Pada bulan Januari sampai Februari berlangsung musim Utara. Sedangkan Maret sampai bulan Juni musim Utara yang berlangsung ${ }^{3}$. Dari berlangsungnya empat musim tersebut, Musim Barat dan Musim Selatan diyakini nelayan sebagai musim yang paling berpengaruh. Pada kedua musim tersebut angin cenderung lebih kencang, sehingga pada periode tersebut nelayan harus bersiasat untuk mendapatkan hasil.

\section{Teknik Pengumpulan dan Analisis Data}

Metode penelitian yang digunakan dalam penelitian ini tidak menggunakan metode survey research - dimana cara kerja diawali dengan menurunkan konsep ke dalam indikator dan kemudian dilakukan verifikasi (deduktohipotetiko-verifikatif), tetapi menggunakan dengan pendekatan grounded theory. Metode grounded theory dari Glaser dan Strauss (1967) berangkat

\footnotetext{
${ }^{2}$ Penilaian diambil dari "Profil Pulau-Pulau Kabupaten Minahasa Utara yang dikeluarkan oleh Departemen Kelautan dan Perikanan Minahasa Utara.

${ }^{3}$ Data didapatkan dari wawancara informan di Pulau Gangga dan Desa Bahoi. Dalam beberapa wawancara dikemukakan bahwa patokan waktu musiman pada dasarnya semakin sulit dibaca, namun tetap dikemukakan dalam tulisan ini sebagai gambaran umum kondisi musim di Kabupaten Minahasa Utara.
} 
dari level empirikal menuju level konseptualteoritikal. Kerentanan sosial dapat teridentifikasi sepenuhnya berdasarkan data lapangan sendiri, baik dalam mendeskripsikan apa yang terjadi dan kemengapaanya. Dengan d emikian apa yang ditemukan (berupa konsep kerentanan, sensisivitas, exposure, resiliensi/kapasistas adaptasi) benarbenar berdasarkan data hasil observasi/wawancara mendalam yang dikembangkan secara induktif.

Untuk mendeskripsikan identifikasi kerentanan sosial dilakukan melalui penafsiran tingkat pertama (the first order understanding) terhadap konsep kerentanan sosial berdasarkan perspektif para pelaku (actors) yang menjadi subyek penelitian itu sendiri. Hasil yang diperoleh dari penafsiran tingkat pertama menjadi "bahan baku" untuk penfasiran tingkat kedua (the second order understanding) yang berguna untuk membantu analisis resiliensi sosial budaya masyarakat pesisir akibat perubahan iklim (Giddens, 1984).

Metoda yang dipakai dalam pengumpulan data lapangan dilakukan dengan tiga cara, yaitu: observasi, wawancara mendalam (indepth interview) dan Focus Group Discussion (FGD). Observasi dilakukan untuk mengetahui kondisi lingkungan fisik masyarakat pesisir beserta perubahanperubahannya, termasuk kondisi permukimannya. Wawancara mendalam dilakukan untuk mengetahui persepsi masyarakat terkait perubahan iklim yang terjadi dan dampaknya, baik terhadap lingkungan fisik maupun lingkungan sosialnya, serta berbagai upaya yang dilakukan masyarakat untuk mengatasi resiko perubahan iklim tersebut.

Jika wawancara mendalam dilakukan dengan masyarakat secara individual, maka FGD dilakukan dengan perwakilan dari unsur-unsur yang ada dalam masyarakat, seperti kelompok-kerlompok nelayan, pedagang ikan dan kelompok sosial lainnya, untuk memperdalam jawaban masyarakat yang bersifat individual tersebut. Dengan demikian melalui FGD dapat dilakukan sinkronisasi dari persepsi masyarakat yang bersifat individual tersebut. Untuk melengkapi data primer tersebut, juga dilakukan pengumpulan data sekunder, terutama data statistik perikanan dan kelautan.

\section{KAPASITAS ADAPTIF MASYARAKAT}

Untuk dapat memahami kapasitas adaptif dari masyarakat pesisir, penting untuk memperjelas definisi konsep tersebut. Kapasitas adaptif dapat didefinisikan sebagai kemampuan atau kapasitas dari suatu sistem untuk memodifikasi atau mengubah wataknya untuk dapat lebih baik mengatasi tekanan yang sudah ada maupun yang akan terjadi (Adger et al., 2004). Dalam konteks ini tekanan yang dimaksudkan adalah perubahan iklim yang gejalanya sudah dapat dirasakan di wilayah pesisir Minahasa Utara.

Persoalan perubahan iklim merupakan fenomena yang nyata di Pulau Gangga. Cuaca yang sebelumnya dapat diperhitungkan nelayan dengan beragam cara, tidak dapat dibaca pada periode sekarang. Hal ini berdampak langsung pada pola-pola mata pencaharian mereka. Nelayan di Pulau Gangga diharuskan menyiasati cara-cara mereka menangkap ikan. Pada periode angin kencang misalnya mereka akan mencuri waktu mencari ikan dalam jam atau hari yang aman. Persoalannya siasat semacam itu sulit untuk bisa diterapkan terus menerus karena unsur kepastiannya sangat rendah.

Dalam FGD yang dilakukan di Pulau Gangga, informan-informan belum merasakan kesulitan yang signifikan akibat gejala perubahan iklim tersebut. Meskipun mereka mengakui hasil ikan sudah berkurang, namun belum berdampak besar pada pengurangan ekonomi mereka. Artinya permasalahan yang ada dianggap masih dalam tahap wajar dan belum mempersulit hidup sehari-hari. Meskipun demikian hal ini sama sekali tidak berarti bahwa Penduduk Pulau Gangga lepas dari ancaman perubahan iklim, karena kecenderungan ancaman tersebut tetap meningkat.

Persoalannya terletak pada strategi mengidentifikasi kapasitas adaptif masyarakat Pulau Gangga. Adger et al., (2004) mengatakan bahwa pada tingkat individu kapasitas adaptif terhadap perubahan iklim dapat dilihat sebagai fungsi dari kemampuan mereka untuk mengakes berbagai macam sumber daya. Artinya, individu yang memiliki lebih banyak akses terhadap sumber daya memiliki kapasitas adaptif yang lebih tinggi daripada yang sedikit atau tidak memiliki akses sama sekali.

Bagi Adger et al., (2004) pendekatan berbeda harus digunakan ketika membaca kapasitas adaptif dalam tataran komunitas. Kapasitas adaptif dalam tataran komunitas sangat menekankan kesiapan kolektif untuk bertindak menghadapi ancaman perubahan iklim. Oleh karenanya, kapasitas adaptif sebagai bagian dari keseluruhan kerentanan masyarakat dapat dijelaskan dengan memeriksa 
institusi-institusi dalam pengelolaan sumber daya, tingkat efektivitas, efisiensi, dan legitimasi (Adger et al., 2004). Maka kapasitas adaptif masyarakat di Pulau Gangga dapat dilihat dari institusi yang mengelola sumber daya di sana. Dalam pembicaraan mengenai kapasitas adaptif, institusi yang berngaruh pada tingkat desa dapat dilihat representasi nyata dari konsep modal sosial. Seperti yang didefinisikan Robert Putnam, modal sosial adalah sifat-sifat dari kehidupan sosial (jaringan, norma, dan kepercayaan) yang memungkinkan partisipan untuk bertindak bersama dengan lebih efektif untuk mengejar tujuan bersama (1995). Oleh karena itu pembacaan terhadap institusi merupakan pembacaan mengenai cara modal sosial tersebut beroperasi pada masing-masing desa. Di Desa Gangga 2, institusi yang melibatkan jaringan nelayan satu desa adalah masjid. Dalam setiap hasil tangkapan kapal, desa sudah menetapkan kesepakatan untuk memberikan bagian bagi masjid.

Pembagian hasil dapat dilihat melalui ilustrasi penghasilan nelayan. Sebagai asumsi, ada kelompok neleyan yang sudah memeroleh hasil bersih senilai dua puluh juta. Angka tersebut didapat setelah memotong biaya penjualan dengan biaya operasional. Dari hasil bersih tersebut, uang dibagi menjadi dua bagian. Sepuluh juta rupiah diperuntukkan bagi pemilik perahu, sedangkan sisanya merupakan bagian anak buah kapal, mesin, dan masjid. Masjid berhak mendapatkan satu bagian, begitu juga awak kapal berhak mendapatkan masing-masing satu bagian. Satu mesin biasanya dihitung dengan jatah dua bagian, artinya jika tiga buah mesin memiliki jatah enam bagian. Jatah mesin ini biasanya diperuntukkan bagi anak buah kapal yang dianggap penting atau giat. Dari ilustrasi ini dapat dilihat bahwa sepuluh juta tadi akhirnya dipecah ke dalam tujuh belas bagian.

Dari definisi mengenai modal sosial maupun kapasitas adaptif, pengelolaan sumber daya adalah kunci dari peningkatan kapasitas adaptif. Sejauh ini dana yang dikumpulkan dan dikelola masjid belum ada digunakan untuk pengelolaan sumber daya. Dana yang ada baru digunakan untuk pengelolaan masjid sehari-hari. Dapat diambil kesimpulan bahwa modal sosial dalam bentuk institusi semiformal yang terdapat dalam masjid di Desa Gangga 2 belum berfungsi optimal.

Desa Gangga 1 memiliki persoalan yang berbeda. Desa Gangga 1 memiliki tingkat keragaman religius yang lebih tinggi daripada Desa Gangga 2. Dalam desa yang dihuni 471 kepala keluarga ini terdapat beberapa gereja. Jarak antara bangunannya pun tidak lebih dari seratus meter. Ragam ajaran agama ini tidak membuat penduduk Desa Gangga 1 berkonflik, namun menyulitkan penduduk desa untuk memiliki dana yang dikelola bersama seperti di Desa Gangga 2. Gereja mengumpulkan dana dari jamaahnya masing-masing, itupun bersifat sukarela. Hal ini berbeda dengan pengumpulan dana masjid Desa Gangga 2 yang berupa kesepakatan bersama.

Ketiadaan dana bersama tidak menjadikan kapasitas adaptif di Desa Gangga 1 menjadi lebih buruk. Keberadaan hukum tua dan perangkat desa lainnya membuat desa tersebut memiliki peran yang lebih aktif dalam pengelolaan sumber daya. Hukum tua Desa Gangga 1 beserta hukum tua dari pulau-pulau lain di sekitarnya telah membuat kesepakatan mengenai perlindungan terumbu karang. Perlindungan terumbu karang merupakan isu yang sangat penting karena berkaitan langsung dengan keberlanjutan hasil laut. Maraknya penggunaan bom dan potassium untuk menangkap ikan adalah ancaman nyata bagi para nelayan. Dengan melakukan patroli bersama antar pulau, tingkat perusakan ini bisa diredam meskipun tidak hilang sama sekali.

Upaya lain pengelolaan sumber daya di Desa Gangga 1 dapat dilihat dari pengadaan sumur resapan. Desa Gangga 1 memiliki lebih sedikit sumber air daripada Desa Gangga 2. Akibatnya, pada musim kemarau Desa Gangga 1 akan sangat kesulitan air untuk menjalankan aktivitas seharihari. Untuk mengatasi persoalan tersebut, Desa Gangga 1 membuat sumur resapan di area hutan yang terletak di belakang desa. Meskipun kesulitan, sumur tersebut menjadi satu-satunya andalan warga desa kala musim kemarau tiba.

Dari dua kasus desa tersebut, dapat dilihat adanya dua pola berbeda yang dikembangkan masing-masing desa. Desa Gangga 2 mampu menjadikan modal sosial ke dalam bentuk institusi informal yaitu kegiatan masjid. Desa Gangga 1 mampu menggunakan institusi formal untuk menggerakkan aktivitas yang berperan aktif dalam pengelolaan sumber daya. Dari dua pendekatan tersebut Desa Gangga 1 dapat dikatakan memiliki kapasitas adaptif yang lebih baik karena institusinya sudah bergerak mengenai pengelolaan sumber daya dalam tataran kolektif. Meskipun demikian, upaya-upaya yang dilakukan oleh kedua desa 
tersebut belum dapat dikatakan cukup untuk mengantisipasi perubahan iklim. Sebab selain kapasitas adaptif dalam tataran kolektif, pembacaan kapasitas adaptif tingkat individu juga penting dilihat. Kapasitas adaptif individu dapat dilihat dari strategi yang digunakan untuk mengatasi persoalan akibat perubahan iklim.

\section{STRATEGI TINDAKAN MASYARAKAT}

Seperti yang telah dikemukakan sebelumnya, kapasitas adaptif dalam tingkat individu amat ditentukan dari akses terhadap sumber daya. Kemampuan individu untuk memperbanyak akses pada sumber daya amat menentukan kapasitas adaptifnya terhadap perubahan iklim. Di Pulau Gangga terdapat beberapa pola serupa yang dilakukan sebagai upaya penduduk menyiasati masalah perubahan iklim yaitu :

a. Berganti pekerjaan sementara pada musim angin kencang

b. Bersiasat dengan kontur pulau dan waktu melaut

Tindakan berganti pekerjaan, adalah hal yang cukup lazim dilakukan di Pulau Gangga terutama pada periode angin yang sangat kencang. Untuk mencari pekerjaan sementara, buruh nelayan di Pulau Gangga pergi ke pulau yang lebih besar. Ada beberapa pekerjaan yang dapat dijadikan alternatif, buruh kelapa, buruh bangunan, dan buruh cengkih. Buruh kelapa mendapatkan bayarannya dengan sistem bagi hasil antara pemilik kelapa dengan pemetik kelapa. Sistem pembayaran berbeda diterima nelayan yang menjadi buruh bangunan, mereka mendapatkan bayaran berupa uang tunai, berkisar antara 60.000 sampai 100.000 per hari. Pembayaran pada buruh cengkih jug a menerapkan sistem yang berbeda dengan perhitungan seribu rupiah untuk setiap liter cengkih. Alternatif pekerjaan ini pada umumnya tidak dilakukan lebih dari sebulan. Sebab sebagian besar nelayan masih mengandalkan pencarian ikan sebagai sumber pendapatan yang utama.

Tidak semua nelayan berganti pekerjaan pada periode angin kencang. Sebagian nelayan memilih tetap melaut sambil bersiasat agar tidak terancam bahaya angin. Kontur pulau adalah celah yang biasa dimanfaatkan nelayan untuk tetap melaut. Jika angin datang dari arah Selatan pulau, nelayan akan melaut di sisi Utara pulau, dan sebaliknya. Wilayah Timur dan Barat tidak dapat dimanfaatkan untuk berlindung karena bentuk Pulau Gangga yang memanjang. Cara lain menyiasati angin kencang adalah dengan melaut di antara jam-jam yang tenang. Cara seperti ini sering dilakukan nelayan meski dengan risiko dihantam angin kencang saat di tengah laut.

Kemampuan akses sumber daya adalah kunci peningkatan kapasitas adaptif pada tingkat individu. Dari dua jenis strategi yang dikembangkan masyarakat, pola yang pertama lebih dekat dengan upaya peningkatan kapasitas adaptif. Sebab berganti pekerjaan adalah upaya untuk memperbanyak akses pada sumber daya. Sebaliknya, strategi yang kedua belum mampu meningkatkan kapasitas adaptif dalam tataran individu karena tidak ada upaya diversifikasi sumber daya

\section{HAMBATAN PENINGKATAN KAPASITAS ADAPTIF}

Pada pembahasan sebelumnya telah dikemukakan kapasitas adaptif dalam tataran kolektif maupun individual di Pulau Gangga. Di luar kelemahan-kelemahan kapasitas adaptif yang ada, masih ada beberapa permasalahan yang menghambat peningkatan kapasitas adaptif masyarakat setempat. Pertama, masih rendahnya kesadaran masyarakat terhadap ancaman perubahan iklim. Dalam wawancara maupun FGD ditemukan bahwa meskipun perubahan iklim menjadi fenomena yang dirasakan langsung, penduduk tidak merasa bahwa persoalan tersebut masalahan yang mendesak. Sedikit banyak hal ini dipengaruhi oleh ragam faktor yang memengaruhi kurangnya hasil ikan. Dalam salah satu wawancara misalnya, nelayan setempat lebih menyalahkan kapal asing yang modern sebagai penyebab berkurangnya ikan. Baginya perubahan iklim bukan sesuatu yang mudah dilihat atau dibuktikan, sebaliknya kapal asing yang modern jelas menangkap ikan yang menjadi buruannya. Dalam jangka panjang tidak adanya kesadaran ini dapat meningkatkan kerentanan masyarakat Pulau Gangga. Karena tidaklah mungkin ada peningkatan kapasitas adaptif jika tidak ada kesadaran warga terlebih dahulu.

Kedua, peran tibo-tibo yang memiliki modal sosial paling kuat dapat berpengaruh pada kapasitas adaptif tingkat kolektif. Tibo-tibo selama ini menjadi patron dari nelayan-nelayan di Pulau Gangga. Selain berperan aktif menentukan harga, tibo-tibo dapat juga menjadi pemberi hutang bagi nelayan. Jika diperhatikan tibo-tibo lebih memiliki 
kemampuan untuk mengakumulasi pendapatan daripada nelayan. Oleh karena itu jelas terlihat adanya ketimpangan di antara tibo-tibo dan nelayan dalam hal ekonomi. Kajian Peeling dan Dill (2010) menunjukkan bahwa relasi patron-klien yang tidak seimbang dapat menjadikan individu tertentu menaikkan posisinya dalam akses sumber daya. Artinya, kemampuan akses sumber daya individu yang berlebihan berpotensi untuk mengurangi akses individu lainnya. Ketimpangan semacam ini tentu saja dapat memengaruhi kapasitas adaptif di tingkat kolektif. Dua permasalahan di atas perlu untuk diatasi jika masyarakat Pulau Gangga mau meningkatkan kapasitas adaptifnya dalam menghadapi perubahan iklim.

\section{PENUTUP}

Perubahan iklim tidak selalu menimbulkan bencana bagi masyarakat pesisir karena hal ini terkait dengan kondisi kerentanan yang diakibatkan. Dampak perubahan iklim pada sistem matapencaharian masyarakat pesisir hanya dirasakan sebagai perubahan orientasi bekerja untuk menghindari gangguan musim bekerja. Dampak perubahan iklim yang terjadi ini setidaknya hanya berpengaruh pada kerugian karena modal produksi yang hilang akibat gagal panen atau tidak pernah pernah mendapatkan hasil dalam beberapa kali fishing trip sehingga tidak mampu lagi menyediakan modal kerja.

Kelompok marjinal pada masyarakat pesisir akan semakin terpuruk kondisinya jika terjadi bencana alam, seperti kegagalan panen, kondisi cuaca yang tidak bisa melaut. Kerugian yang terjadi secara terus menerus akan berakibat pada ketidakmampuan bekerja secara rutin untuk pekerjaaan yang sama karena tidak ada lagi modal kerja, Pada sistem matapencaharian yang bersifat perorangan jika terjadi kerugian akan menyebabkan terjadi perubahan orientasi pekerjaan atau berganti pekerjaan, sementara pada sistem matapencaharian kolektif, kerugian perorangan tertolong dengan sistem patron-client. Resiko kerugian akibat perubahan iklim akan ditanggung bersama atau ditanggung oleh patron.

Ketidakberlanjutnya matapencaharian yang sama dan beralihnya ke matapencaharian lain yang lebih buruk kondisnya (semakin miskin), dan hutang untuk menopang modal kerja yang tidak dapat dikembalikan dan bahkan semakin bertambah adalah terjadi indikasi kerentanan secara individual. Kerentanan sosial lebih banyak disebabkan oleh faktor sosial-budaya, seperti penguasaan lahan, sistem relasi sosial, sistem bagi hasil, sistem jaminan sosial tradisonal, dan distribusi resiko atas kerugian yang diakibatkan kegagalan hasil dan jenis matapencaharian

Ada beberapa langkah esensial yang dapat menjadi prioritas dalam mengatasi dampak perubahan iklim. Pertama, sosialisasi urgensi gejala perubahan iklim dan dampaknya terhadap kehidupan masyarakat.Kesadaran ini penting ditingkatkan, karena pada dasarnya gejala perubahan iklim berdampak pada kehidupan semua orang. Dalam jangka panjang kerugian sosial maupun ekonomis akan makin dirasakan semua pihak. Oleh karena itu, sosialisasi dapat membuat banyak orang merasa penting untuk terlibat dalam upaya adaptasi dan mitigasi. Kedua, mengupayakan akses informasi arus dan cuaca baik dari data Kementerian Pertanian maupun BMKG. Akses informasi ini menjadi penting karena persoalan cuaca dan arus secara nyata berdampak langsung pada kehidupan masyarakat.

\section{PERSANTUNAN}

Artikel ini bagian dari hasil penelitian Penyusunan Indikator Kerentanan Sosial Budaya Masyarakat Pesisir Akibat Perubahan Iklim yang didanai oleh Anggaran Puslit Geoteknologi LIPI tahunAnggaran 2013. Untuk itu, saya mengucapkan terima kasih kepada Dr. Heru Santosa, Koordinator Sub. Program Perubahan Iklim - Geoteknolog Program Prioritas Nasional 09-LIPI.

\section{DAFTAR PUSTAKA}

Acheson, J. M. 1981. "Anthropology of Fishing" dalam Annual Review of Anthropolog", pp. 275-307.

Adger, W., Brooks, N., Kelly, M., Bentham, G., Agnew, M., and Eriksen, S., (2004): New indicators of vulnerability and adaptive capacity; Tyndall Centre, Technical Report.

Glaser, B. G., and Strauss, A. L. 1967. The Discovery of Grounded Theory: Strategies for Qualitative Research. Aldine, pp. 271.

Giddens, A. (1984). The Constitution of Society: Outline of the Theory of Structuration, Cambridge: Polity Press. 
Mirjam Macchi, Amanda Manandhar Gurung, Brigitte Hoermann, Dhrupad Choudhury. 2011. Climate Variability And Change In The Himalayas Community Perceptions And Responses. Nepal : International Centre for Integrated Mountain Development]. Hal. 1.

Susan L. C., 2003. Social Vulnerability To Environmental Hazards. In Social Science Quarterly, Volume 84, Number 2, June 2003.
Seth Tuler, Julian Agyeman, Patricia Pinto da Silva, Karen Roth LoRusso, Rebecca Kay., 2008. Assessing Vulnerabilities: Integrating Information about Driving Forces that Affect Risks and Resilience in Fishing Communities. Human Ecology Review, Vol. 15, No. 2, 2008 